3. The urit of the measure of capacity, as well for liquids as for dry goods, shall be the cube of a tenth of the metre, and the same shall be and is hereby denominated the "litre."

4. The unit of weight shall be and is hereby denominated the "gram." A thousand grams shall be and is hereby denominated the "kilogram." A standard of the kilogram shall be prepared un ler the authority of the Privy Comncil for Trade, verifed by comparison with the original standards in Paris, and have the words "Standard Kilogram, I 871 ," engraved upon it, and the same shall be kept in the custody of the Warden of the Standards.

5. For the more convenient use of metric weights and measures, it shall be lawful to take the double and the half of all the said units, and their decimal multiples and decimal parts.

6. The said weights and measures hereby established shall be and are hereby denominated the standard metric weights and measures, as shown in the table hereto amnexed.

7. Copies and models of the same standard metre and kilogram shall be sent to the Lord Mayors of London and Dublin, to the Lord Provost of Edinburgh, and to all counties, shires, stewartries, ridings, divisions, cities, towns, liberties and places in which by law copies and models of the standard imperial weights and measures are required to be kept, and to such other places and persons as the President of the Committce of the Privy Council for Trade may from time to time direct.

8 . All judges, magistrates and other person or persons who now are or shall hereafter be authorised by law to order or pro. vide copies of the present imperial standard weights and measures, shall at all times hereafter have like power and authority in every respect to order and provide copies of the standard metric weights and measures, and to charge the expenses thereof upon the fund or funds, money or moneys, that would have been liable in case it had been copies of imperial weights and measures that had been ordered or provided.

9. All and every the provisions and provision which are by law in force with respect to the inspection, verification, revelification, stamping, counterfeiting and mode; of conviction, with the penalty or penalties relating thereto, of the present imperial standard weights and measures, shall apply to and be in force with regard to the standard metric weights and measures in every respect as if the said standard metric weights and measures were comprised in and designated by the imperial weights and measures in the Acts relating to such inspection, verification, reverification, stamping, counterfeiting and modes of conviction, and the penalty or penalties relating thereto as aforesaid.

Io. From and after the expiration of ( ) years from the passing of this Act, the imperial and all local or customary weights and measures shall be abolished, and every person who shall sell by any denomination of weights or measures uther than those of the standard metric weights and measures, or such decimal multiples or decimal parts therecf as are authorised by this Act, shall, on conviction, be liable to a penalty not exceeding the sum of $40 s$. for every such sale.

II. From and after the expiration of ( ) years after the pass. ing of this Act, if any person or persons shall print, or if the clerk of any market or other person shall make any return, price list, price current, or any journal or other paper containing price list or price current in which the denomination of weights and measures quoted or referred to shall denote or imply a greater or less weight or measure than is denoted or implied by the same denomination of the metric weights and measures under and according to the provisions of this Act, such person or persons or clerk of the market shall forfeit and pay any sum not exceeding 10s. for every copy of every such return, price list, price current, journal, or other paper which he or they shall publisls.

12. As soon as conveniently may be after the passing of this Act, accurate tables shall be prepared and published, under the authority of the Committee of Privy Council for Trade, showing the proportions between the imperial weights and measures heretofore in use and the standard metric weights and measures hereby established, with such other conversions of weights and measures as the said Committee of the Privy Council for Trade may deem necessary, and after the publication of such tables all future payments to be made shall be regulated according to such tables.

13. And whereas the weights and measures by which the rates and duties of the customs and excise and other Her Majesty's revenue have been heretofore collected, are different from the metric weights and measures directed by this Act to be used : It is hereby enacted, that so soon as conveniently may be after the passing of this Act, accurate talles shall be prepared and pub. lished under the direction of the said Committee of the Privy Council for Trade, in order that the several rates and duties of customs and excise, and other Her Majesty's revenue, may be adjusted and made payable according to the respective quantities of the standard metric weights and measures directed by this Act to be used, and that on the expiration of () years after the passing of this Act, the several rates and duties thereafter to be collected by any of the officers of Her Majesty's ctistoms or excise, or other Her Majesty's revenues, shall be collected and taken according to the calculations in the tables to be prepared as a!oresaid

14. From and after the passing of this Act, and until the nse of the metric weights and measures shall be made compulsory, the said metric weights and measures shall be deemed and taken to be legal weights and measures, and as such may be used $f, r^{*}$ all purposes whatsoever.

15. As soon as conveniently may be after the passing of this Act, the metric standards to be provided under this Act shail be placed in the custody of the Warden of the Standards, and the Committee of the Privy Council for Trade shall cause the metric weights and measures in use under the present Act to be verified and stamped in the same manner as the imperial weeignts and measures are now required to be.

16. From and after the passing of this Act the "Metric Weights and Measures Act, 1864 ," shall be and is hereby repealed.

\section{FLOATING ISLANDS IN VICTORIA}

GIPPSLAND is a prevince of Victoria. It is bounded by the Australian Alps on all sides except on the south, which the sea washes for over 100 miles. It may be called the Piedmont of Australia, rich fertile plains intersected by rivers fiowing into a lake system extending all along the coast, and separated from the sea by a sandy narrow ridge, with one navigable opening. From a local paper, the Cippsland Times, I send the following description of "floating islands" on the lakes.

The alluvial deposit constantly brought down from the mountain ranges by the numerous rivers in this district, enables us to see a very decided process of land making continually going on, and thus tea:hes a usetul lesson in geology.

Melbourne

AUSTRAL-ALPINE

"As one of the Gippsland Steam Navigation Company's steamers was recently crossiny Lake Wellington, the man at the wheel suddenly observed land right in the track of the steamer, apparently only a short distance from the straits separating Lakes Wellington and Victoria. He called the captain's attention to the strange sight, and on coming up close, the land was discovered to be a small island, about thirty yards in length by twenty broad. It was covered with a rich coating of luxuriant grass ; and small trees, tea tree, and bush shrubs appeared to be growing in profusion. The only occupan:s of this remarkable apparition were a few pigs, feeding au ay contentedly and apparently enjoying their novel journey by water. A second island of the same description, but much. smaller, was noticed a little farther on, but this had evidently detached itself from the larger piece of land, or most probably had been separated by the rooting depredations of the porkers. From what porion of the main land this floating island came, is, of course, matter of con. jecture, but it is known that a portion of the soil at Marley Point, on the southern shore of Lake Wellington, became detached recently, and floated miles across the lake with some twenty or thirty head of pigs aboard. As long as the wind drove it in that direction, the island drifted towards M'Lennan's Straits, but a change of wind brought it back again, after a three days' trip, within a mile of the spot from which it had broken away. We believe it is the opinion of the district surveyor, Mr. Dawson, that the area of the Roseneath run, west of Lake Wellington, has been increased some twenty or thirty acres by the addition of drift islands." 